\title{
THE CRISIS MANAGEMENT SYSTEM AND THE CIVIL PROTECTION SYSTEM. SIMILARITIES, DIFFERENCES, POSSIBILITIES OF STANDARDISATION
}

\author{
Grzegorz PIETREK, PHD \\ Banking University, Gdansk, Poland \\ gpietrek@wsb.gda.pl
}

\begin{abstract}
Crisis management, civil protection and civil defence are terms which are used every day by theoreticians and practitioners. Are they really different or are they synonyms? Using various research methods (analysis of expert literature, analysis of legal acts, comparison, synthesis and reasoning) in the following article, the author makes an attempt at providing answers to such questions. The article also presents the author's opinion on the future of the above-mentioned systems, indicating that with some modification and legal regulations, it would be possible to develop a uniform system which would be able to function efficiently in crises, emergency situations, during armed conflicts or in a time of war, providing a proper level of management to all the operations involving civil protection and rescue services.
\end{abstract}

Key words: crisis management, civil protection

\section{Introduction}

The term crisis management entered terminology for good just after the end of the Cold War. The term actually replaced another one, namely: civil defence, which was already exhausted in its Cold War aspect at the end of the $20^{\text {th }}$ century. At the end of the Cold War, civil defence was defined as undertakings which could considerably decrease the results of any forms of armed operations in the civil 
population, including conventional, nuclear, chemical and biological attacks. Such undertakings were generally of a passive nature, not connected with any defensive operations under the command of the armed forces (Compendium of Guidelines for the Basic Protection of Population 1986).

In a new environment of safety, in a new reality, such a formation could not replace non-military protection, the significance of which was still growing - one of the pillars in the foundations of national defence - despite the fact that such values were assigned to it by national expert literature even after the year 2000 . The discussed changes were acknowledged at the beginning of the 1990s when the downsizing of the armed forces was commenced.

Understood as performance of humanitarian tasks, civil defence used to perform an important role in civil protection during the times when the threat of weapons of mass destruction weapon was real. Considering its fundamental assumptions, at that time the structures of civil defence were usually located at the Ministry of Defence at that time. The new safety conditions, however, required some changes because so far the tasks performed by civil defence so far had come down to two or three stages:

- preparation for the a global war;

- response of theto a global war outbreak;

- general reconstruction after total destruction (done by nuclear weapons); (Gołębiewski 2015, p. 60).

As it follows, It followed that preparations were made with regard to a war, with thea possibility to useof using the structures of civil defence in the time of peacepeacetime. Considering the new conditions, there were numbers a number of terms which required redefinition, solutions which needed to be found and new concepts to be formulated. The aim was to develop a new, integrated system which would include all the entities and the whole of society.

First of all, new solutions included recognition and elimination of risk factors, risk modelling, prevention of threats and reconstruction after a disaster which would meet all the requirements. Such an approach emphasized emphasised the universal character of systemic solutions, integration of systems in terms of their capabilities to face all potential threats and their civil (non-military) character. 


\section{An outline of the crisis management system}

Crises and emergency situations which have been experienced in Poland have made the legislator define the terms of a crisis and crisis management in a precise way. Such regulations allow us to provide a definition of the crisis management system. At this point, it is possible to accept a qualitative definition which indicates that the system is a purposefully defined set of elements and a set of linkages between them which together define the characteristics of the entirety (Beer 1966, p. 41). It should be noticed noted that the provision of system purposefulness plays a significant role and, at the same time, it generates the criteria that allow us to distinct distinguish the system. Another significant issue refers to efficiency because it is most important for the functioning system to be efficient. It means that the system should perform its tasks in the defined time. The efficiency of the system first of all consists of relationships among all the elements which are included in the structure of an organisation and the process of information exchange among them.

Summing up the above-presented considerations above, it is possible to assume that the organisation is Poland (where the crisis management system is operated), which has achieved its aims through the functioning of various systems run by different entities. Poland has a system which can be applied to prevent crises, and if they appear - it is possible to minimise their results in a professional way.

Grzegorz Krasnodębski defines the crisis management system as a set of bodies and institutions of state administration which are mutually related and the main aim of their operation is to implement the process of crisis management (Krasnodębski 2013, p. 82).

Andrzej Szymonik extends his definition of the crisis management system to the operation of numerous institutions and economic entities performed in favour of life maintenance and development during emergency situations. The system is composed of the following sub-systems:

- crisis responsesub-system - a set oforganisational units, legal and natural persons and their mutual relations and procedural principles during operations; 
- managing sub-system - it includes the organisational and functional structure of informational and decision-making activities which are performed in order to achieve the required aim (Szymonik 2012. p. 57).

The Government Centre for Security states that the crisis management system of Poland consists of the following elements:

- crisis management authorities (the Council of Ministers, the Prime Minister, a minister who is responsible for the operations carried out by state administration, a head of the central body, a provincial governor (voivode), a starost, a village head, a mayor or a town president ;

- authorities providing opinion and advice, responsible for the initiation and coordination of operations undertaken in crisis management (crisis management teams);

- crisis management centres which are ready for operation for 24 hours a day (crisis management centres); (www.rcb.gov.pl [accessed: 9.06.2017]).

The role of crisis management teams comes down to providing opinion and advice during the initiation and coordination of operations which are undertaken in crisis management, whereas the role of crisis management centres is to monitor and supervise emergency situations in the country, to coordinate operations and to cooperate with crisis management centres of other state administration bodies.

Krzysztof Ficon states that the crisis management system, the final result of which is most frequently a more or less anticipated crisis, comes as an integral part of a meta-system of organisational management; the system provides the proper functioning of an organisation during an emergency situation, the intensity of which changes, including any potential crisis. The system comes as an integrated set of management authorities which are linked by various functional relationships, including material, energy-related, official relations, and by methods and principles which are applied to lower reduce the crisis risk and to minimise its results. In order to achieve that aim, proper management decisions are made to prevent unfavourable development of the crisis situation and to efficiently fight against any negative results and consequences of the crisis (Ficoń 2011, p. 109). 


\section{Relations of the systems: crisis management, civil protection and civil defence}

The crisis management system is aimed at a decrease reduction in the risk that results from any potential threats and at the development of operations which shall ensureensuring that the security of people, protection of critical infrastructure and the natural environment shall beis provided (Sobolewski 2013, p. 45). Thus, it is one of the most important systems which affect the functioning of the state and its citizens' sense of security. Therefore, it is possible to assume that the primary aim of the operation of such a system is the implementation of tasks which provide proper civil protection. At present, proper civil protection should be understood as a set of operations undertaken by relevant state authorities, rescue entities, humanitarian organisations and citizens themselves in order to provide security to the whole of society (Strategia Sprawne Państwo 2020, p. 24).

Waldemar Kitler defines civil protection in a different, broad way. He identifies it as one of the fundamental missions implemented for national security by state administration authorities, other state bodies and state institutions, entrepreneurs and other organisational units, non-government organisations and citizens themselves, and in some justified cases by the armed forces. Such a mission involves the implementation of numerous preventive, preparatory, interventional and recovering tasks in order to protect human life and health, to protect property, objects of cultural legacy and the natural environment to the extent indispensable for survival. The mission also involves any humanitarian and legal aid provided during catastrophes, natural disasters, armed conflicts and occupation and directly after such events (W. Kitler \& A. Skrabacz 2008, pp. 67-68).

Expert literature provides another interesting opinion on the discussed problem. Aleksandra Skrabacz defines civil protection as a set of interdisciplinary undertakings implemented by joint efforts made by all entities of the state law who act in order to protect life, health, property and natural environment against any potential danger caused by the forces of nature or by people, to overcome their consequences and to provide conditions indispensable for survival (Skrabacz 2008, p. 312). 
So far, civil protection has not been defined in any currently binding legal act. It is, however, possible to fall back on a draft act on civil protection of $31^{\text {st }}$ August 2009, article 2 which states that civil protection comes as an integrated operation of state administration authorities and entities which implement tasks of civil protection in order to provide security to citizens, public order, protection of life and health of people who reside in the territory of Poland, protection of property, the natural environment and cultural legacy in any cases of potential threats (The draft Act on Civil Protection, art. 2).

The above-mentioned draft act defines the principles referring to the organisation and functioning of the civil protection system, relevant authorities responsible for civil protection and their tasks, and entities responsible for the implementation of these tasks. The draft act also defines the principles of alarming and warning, education of people, citizens' rights and obligations. Additionally, the document states the main assumptions of the practical implementation of civil protection, viewed through the prism of the following:

- providing conditions indispensable to protect human life and health, to provide people with basic conditions necessary to survive in emergency situations;

- providing cooperation of all the rescue systems, monitoring, warning, alarming, informing about potential threats, also units, services and other entities which implement tasks for civil protection;

- providing substantive, organisational, material and financial support to the operations implemented by non-government organisations which perform tasks for civil protection, particularly to social rescue and humanitarian organisations and voluntary service;

- organisation and coordination of humanitarian aid;

- maintaining resources which may be used to implement tasks for civil protection;

- providing education to society to increase awareness of potential threats and to teach proper behaviour in case such threats should take place.

Based on the above-mentioned range of tasks and a pragmatic approach towards the problem of civil protection, it is advisable to pay some attention to the institutional context of their implementation, that is namely: specification of entities which are competent to perform such tasks. There is another important opinion worth noticingnoting. It has been provided by Romuald Kalinowski 
who sees civil protection as an institution (in this case: a formation) that is: Civil Protection. For Kalinowski, civil protection - considered in a systemic approach as well as in an individual one - is significant because of the legal and humanitarian approach of various entities towards that question. He indicates that it is important to provide civil protection to the whole population of the country in the time of peacepeacetime as well as in the a time of war (Kalinowski, 2011, p. 5).

Considering the semantic approach, the above-mentioned W. Kitler states that the term civil defence may refer to: civilians' resistance or civil fighting, non-military protection, civil (non-military) protection, civilians facing threats by civilians, aid and self-aid in the society, social self-defence, civil power used in defensive fightce. It can also describe non-military power and means applied for fight, defence, protection and self-defence; it can refer to the method of fighting with the use of non-military tools, the character, the type and the set of defensive or protective operations performed with the use of non-military tools and activities undertaken by civilians in the face of military and non-military threats (Kitler 2001, p. 14).

Leaving aside the changes which have taken place in the way of understanding the term civil defence is understood, it is possible to assume that it comes as one of the most important components in the national defence system which functions within the framework of the so called non-military defence system. In the world, civil defence operates on the basis provided by the regulations of the Geneva Convention of $12^{\text {th }}$ August 1949, with Amendment Protocols ratified by Poland in 1991. In our country, legal regulations referring to civil defence can be found, first of all, in the Act on General Obligation to Defend the Republic of Poland, of 1967. According to the author, one of the most important concepts which result from the analysis of that document is an indication that organisations (structures) of civil defence in the time of peacetime may be applied for cooperation in fighting against natural disasters, threats to the natural environment, in removing their results, organised and led by other authorities (Krynojewski 2012, pp. 43-44).

Therefore, it is possible to assume that civil defence is aimed at protection of people, places of employment, public facilities, objects of cultural legacy, rescue operations and support provided to victims in thea time of war and at cooperation in fighting against natural disasters, threats to the natural environment and removing their results. It is also possible to clearly conclude clearly that the time 
of the functioning of civil defence functioned has not beenwas not only confined only to theto a time of war (as it is commonly thought) (Krynojewski 2012, pp. 43-44).

Considering the aspect of time of peace $s$ of peacetime and a time of war, some theoreticians state that a division into civil protection during the time of peacepeacetime and civil defence during the wartimetime of war is irrelevant. They claim that regardless of the time, the right notion is civil defence, which in turn should be divided into civil protection, general rescue services (Kalinowski 2011, p. 32), and other tasks. Considering the systemic approach, the abovementioned author, R. Kalinowski sees a great role performed by Civil Defence as one of the leading entities of the national defence system of Poland, that is namely: an organisation based on the structures of state administration which implements humanitarian tasks in order to protect people. Hence, civil defence can be perceived in a very broad sense, and it can be defined as a system of civil protection in Poland which consists of an operational sub-system of Civil Defence, a sub-system of local support, a sub-system of national support and a sub-system of international support.

Following the thoughts of the cited author, it is possible to assume that in general, understanding civil defence refers to structures, tasks, operational principles and forces which provide services to people. Considering When considering the modern character of civil defence, it should be emphasized emphasised that it is based on coordinated operation of forces and resources of all the departments, regional authorities of state administration and self-governments, other units, entities and organisations along with widespread involvement of the whole of society. The implementation of tasks takes place in accordance with the principle of territorial primacy, with the consideration of three-level division of the country, in consistency with the current legal regulations. This is the most proper procedure, considering the aspects of economy and efficiency of operations and responsibility for decisions made in the field of civil protection (Kalinowski, 2011, pp. 104-105).

The above-presented considerations above may lead to a well-grounded conclusion that in our national system, the tasks referring to civil protection against various threats are entrusted to numerous centres, administration structures and self- 
governments. The efficiency of operation is ensured by collective cooperation coordinating rescue actions undertaken by particular entities.

Considering a number of tasks implemented in that field, A. Skrabacz presents their systematisation, divided into three main modes:

- permanent standing-by and ad hoc response - performance of routine activities oriented towards rescue of people, property and the natural environment; elimination of direct results of sudden emergency situations; prevention and counteraction undertaken against any potential threats;

- crisis - response to situations in which any direct threats may lead to a crisis and response during an ongoing crisis;

- armed conflict (war) - civil protection in accordance with the regulations of international law.

Considering the high level of the implementation of undertakings which are aimedataimed at civil protection, the same author also suggests some principles which should systemise such implementation, that is namely:

- primacy of a territorial system; it means that the foundation of the whole model of civil protection is a horizontal system of authorities formed on the basis of a three-level division of the country, in which the department system performs only an auxiliary function;

- one-person leadership and responsibility for the standing-by mode to provide civil protection; it does not mean any resignation from teams who provide opinion and advice, but it implies that a collective body resignation has resigned from making decisions by a collective body;

- the adequacy of the character and scale of a threat and of the level of the state administration authority which should response respond to such a threat; it means that all activities should be performed by the lowest level of competences powers in a particular situation;

- the common character of the civil protection system means that it refers to all the citizens, and it imposes particular tasks and obligations on them, depending on a situation in which the stand-by system is functioning at a particular moment; 
- management and responsibility held by one-person authorities of general administration: a village head, a starost, as the self-government authorities of a borough and a district, and a provincial governor (voivode) who represents government authorities at the level of the province (Kalinowski, 2011, p. 104-105).

Hence, the area in which the tasks of civil protection are implemented is very broad. It is advisable to provide a systematisation of the problem, as L.T. Dziubek suggests. The discussed undertakings are divided by the category of tasks implemented for:

- collective protection - it comes as systemic activity run by relevant institutions; it involves: recognition of threats and alarming, providing proper shelter, evacuation and blackout;

- individual protection - various activities undertaken by citizens who are prepared to behave adequately to in particular situations (Dziubek 2013, p. 202).

In With reference to the above-presented considerations above, it is possible to conclude that further development of civil protection structures is inseparably connected with the development of the crisis management system. In accordance with the legal act, the latter system has been developed in order to carry out preventive and rescue operations and to reconstruct the critical infrastructure in the case event of any potential threat. The system of civil protection in Poland faces numerous challenges, and it has to undergo some inevitable changes. It seems necessary to make the implementation of civil protection tasks cohesive with tasks implemented within the framework of the Act on Crisis Management in such a way that the crisis management system should cooperate and complete activities performed for civil protection. Considering civil defence, it is possible to observe that solutions and structures applied for the tasks are dispersed in various legal regulations, and sometimes they are not covered by any of them. Therefore, it is possible to suggest some regulations in that field, for example:

- definition and introduction of a term of civil protection into legal regulations - so far it has not been done, hence some terminological chaos can be observed in that respect; 
- explicit indication and identification of tasks assigned to state administration authorities in the field of civil protection, and consequently, indication of authorities responsible for the implementation of such tasks at the level of a borough, a district, a province and the country;

- new definition of the way in which the state should implement civil defence tasks referring to the protection of victims of international armed conflicts - it should be considered whether particular entities who perform civil protection tasks should be granted a the status of entities performing civil defense defence tasks in the a time of armed conflict (war) in an automatic, statutory way.

It also seems necessary to provide statutory regulations referring to tasks performed to rescue life, health, property and the natural environment, to provide aid to those who need ad hoc humanitarian support in the time of peacepeacetime and in the a time of emergency. It can be specified in a single legal act which would indicate such elements as: principles of providing humanitarian aid, citizens' obligations in the field of civil protection, programmes of civil protection, methods and principles of informing, warning and alarming, tasks and entities responsible for education and training provided to citizens, shelters provided to people, protection of property in emergency situations, methods and principles of creating resource reserves, definition of the functioning of civil protection during the "W" period; the funding of tasks, and penal regulations.

Such a solution does not come down to the development of new structures. It should be considered whether these are the structures responsible for that question are the structures of the crisis management system or the structures of the civil defence system, all the more that some of the above-mentioned tasks are implemented based on some other legal acts. In order to introduce new solutions, it is first necessary to identify entities of civil protection, because it is possible to assume that they shall be activated during the a state of emergency, and, in the a state of mobilisationmobilisation, they could be transformed into National Defence in the a time of an armed conflict or war.

It seems advisable to place tasks of civil protection and civil defence in the current system of national security as well as in the latest solutions which refer to crisis management and general defence obligations (e.g.: the conscription of Territorial Defence Forces), in order to properly and clearly define the responsibilities competences of territorial self-government authorities. Consequently, it would 
be possible to implement civil protection tasks and to adjust legal regulations to current threats and to improve ways of response responding to such threats.

There is one more conclusion: the perception of the implementation of civil protection tasks takes place through the prism of civil defence. It This is not surprising though, considering the stages of the civil defence development province area (Kalinowski, 2011, p. 224).

\section{Conclusions}

The crisis management system and the civil defence system have a lot in common. Let us have planning for example. At each of their operational levels, bodies and institutions involved into civil defence must follow their plans, as well as it takes placeand at each level of crisis management. The detailed content of civil defence plans and the content of crisis management plans is similar. However, despite the fact that there are some consistencies, it should be emphasized emphasised that the civil defence plan is to be applied during a situation of where there are external threats to national security and during the a time of war, whereas the crisis management plan is to be applied during the time of peacepeacetime. It can be an indication referring to the necessity and tendency to maintain the structures of civil defence in Poland. Although, at present, civil protection is perceived through the prism of crisis management, and, as a result, civil defence is pushed into operation exclusively during the a time of war, it does not mean it cannot be used during a crisis.

A decision made by the government on the Programme of Rescue Services and Civil Protection in 2014-2020 seems to be very promising. It is actually the first document which - in a holistic and complete way - describes the problems referring to the organisation of rescue operations undertaken to protect life, health, property and the natural environment by all public and social entities which perform such tasks ${ }^{1}$.

1 The resolution No. 59/2014 of the Council of Ministers of 29th April 2014 on the acceptance of the Programme of Rescue Services and Civil Protection in 2014-2020. The programme is to define objectives which must be achieved in the field of rescue services 
Crisis management, civil protection and civil defence are terms which are used every day by theoreticians and practitioners. Are they really different or are they synonyms? Using various research methods (the analysis of expert literature, the analysis of legal acts, comparison, synthesis and reasoning) in the following article, the author makes an attempt at providing answers to such questions. The article also presents the author's opinion on the future of the above-mentioned systems, indicating the fact that with some modification and legal regulations, it would be possible to develop a uniform system which would be able to function efficiently in crises, emergency situations, during armed conflicts or in the a time of war, providing a proper level of management to all the operations involving civil protection and rescue services

\section{References}

Beer, S., 1966. Cybernetyka a zarzadzanie. Warszawa, PWN.

Compendium of Guidelines for the Basic Protection of Population. NATO document AC/23-D/791, 1986.

Dziubek, L. T., 2013. Edukacja obronna w Polsce. Poznań. ZYSK i s - ka.

Ficoń, K., 2011. Logistyka kryzysowa. Procedury, potrzeby, potencjat. Warsaw, BELStudio. Gołębiewski, J., 2015. Zarządzanie kryzysowe na szczeblu samorządowym. Teoria i praktyka. Warsaw, Difin.

Kalinowski, R., 2011. Obrona cywilna $w$ Polsce. Siedlce, UPH.

Kitler, W., 2001. Obrona cywilna - szerokie podejście do problematyki cywilnej w obronie narodowej in W. Kitler (ed) Obrona cywilna (niemilitarna) w obronie narodowej III RP. Warsaw, AON.

Krasnodębski, G., 2013. Modelowanie systemu zarzadzania bezpieczeństwem infrastruktury krytycznej państwa. Gdynia, AMW.

Krynojewski, F. R., 2012. Obrona cywilna Rzeczypospolitej Polskiej. Warsaw, Difin.

Skrabacz, A., 2008. Ochrona ludności. in R. Jakubczak, A. Skrabacz, K. Gąsiorek (eds.) Obrona narodowa w tworzeniu bezpieczeństwa Polski w XXI wieku Warsaw, Bellona.

and civil protection in the years 2014-2020, conditions which must be met to achieve such objectives, with all the basic but indispensable legal, financial and organisational instruments. The suggested solutions shall be applied to provide comprehensive support and development of the potential of national security within which an executive sub-system is operated, that is namely: protective capabilities formed by services and organisations which implement rescue and civil protection tasks, along with entities of the crisis management system. 
Sobolewski, G., 2013. Zarzadzanie kryzysowe jako przedmiot badań nauki o bezpieczeństwie. in P. Sienkiewicz, M. Marszałek, H. Świeboda (eds.) Metodologia badań bezpieczeństwa narodowego. vol. V, Warsaw, AON.

Szymonik, A., 2012. Organizacja i funkcjonowanie systemów bezpieczeństwa. Warsaw, Difin.

Strategia Sprawne Państwo 2020, Amendment to the Resolution no. 17 of the Council of Ministers, of 12th February 2013 (item 136) on the implementation of the Efficient State Strategy 2020, p. 24.

The draft Act on Civil Protection of 31st August 2009. www.rcb.gov.pl [9 June2017]. 